\title{
SEJARAH SASTRA ARAB DI ANDALUSIA
}

\author{
Nur Hidayah \\ Jurusan Sastra Arab \\ Fakultas Sastra dan Seni Rupa \\ Universitas Sebelas Maret
}

\begin{abstract}
Arabic literature in Andalusia is a part of the enriching presence of Arab literature in Middle East. Geographically, Andalusia is located in Europe. Arabic literature comes into Europe by Futuhat Islamiyah. Color and pattern in Arabic Andalusian literary, which became known as the Arab Maghreb Literature - opponent of Arabic literature Masyriq - very different from the forms of Arabic literature in the Middle East. Kind of a complex society and Andalusia are from different races and religions with beautiful natural conditions and rich powerful influence for Arabic literature. So that the writers create works that are creative, beautiful, with high imagination and choice of words are easy to understand. Many emerging new literary genres that are not known in Masyriq like Mala Luzum Yalzam, Muwasyah or Mu'aradhah. Many literary works are timeless and be a reference to the works of modern literature in the world. Like Hayy bin Yaqdzan Ibnu Thufail or Thouqul Hamamah Ibn Hazm Al-Andalusia.
\end{abstract}

Keyword: Andalusia, Arabic literature, Hayy bin Yaqdzan, Thouqul Hamamah

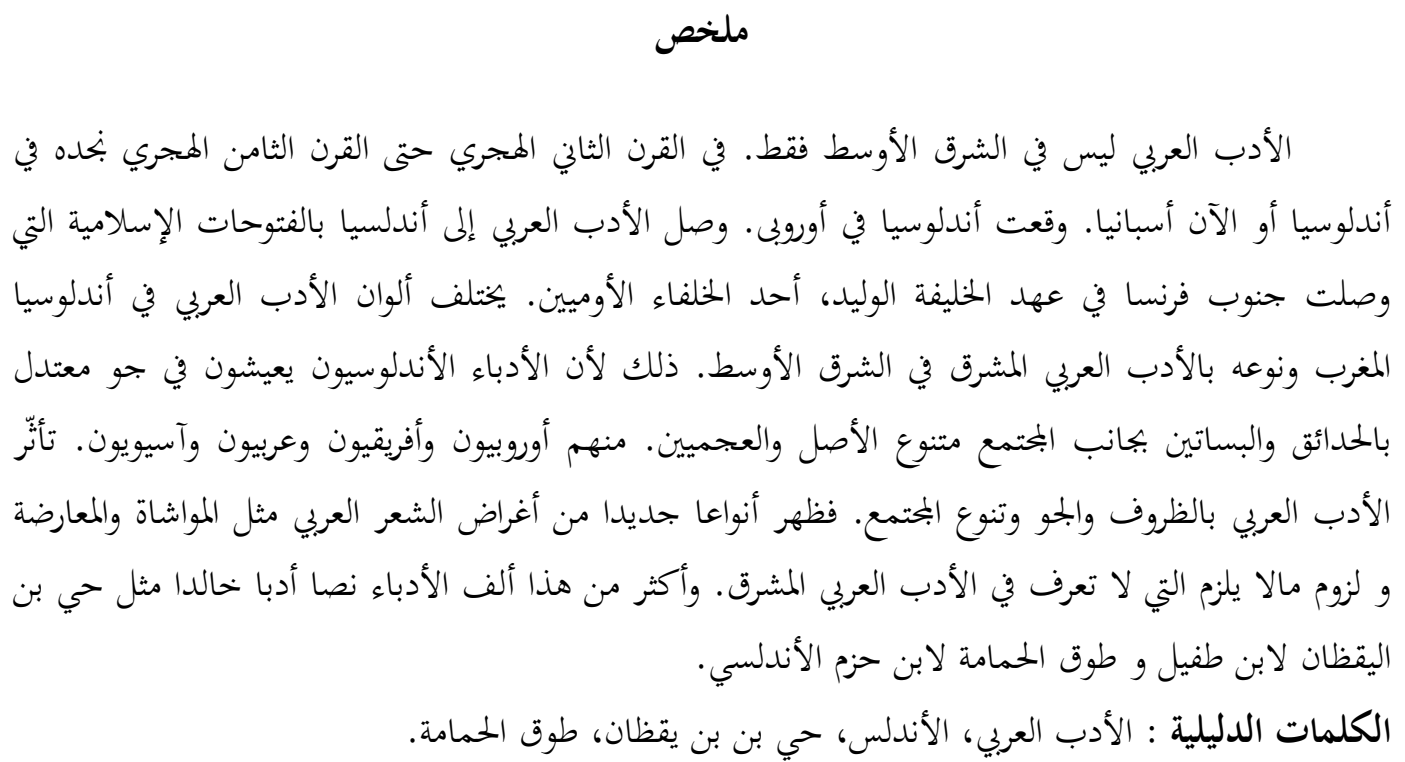




\section{PENDAHULUAN}

Sastra Arab tumbuh dan berkembang jauh sebelum kedatangan Islam. Makkah sebagai kota Islam sudah dikenal karena menjadi pusat pertukaran sastra dengan kebiasaan bangsa Arab dalam memperlombakan syair-syair mereka di pasar 'Ukādz. Kemasyhuran Makkah ini membuat Abrahah ingin membuat tandingan dengan membangun gereja Qulayyis di Yaman. Meski pada kenyataannya hal tersebut tidak menyurutkan kemasyhuran Makkah sedikitpun.

Sejarawan membagi sastra Arab menjadi 6 sastra, yaitu: (a) sastra Jāhilī atau pra-Islam; (b) sastra awal Islam ; (c) sastra Umawī; (d) sastra Abbāsī; (e) sastra pertengahan; dan (f) sastra modern (AlJami'ah, 17). Sastra Jāhilī adalah karya sastra yang muncul 2 abad sebelum Islam, sedang Sastra awal Islam adalah sastra yang muncul pada masa Rasulullah SAW dan Khulafāur-Rāsyidīn. Adapun sastra Umawī dan Abbāsī adalah sastra yang muncul zaman Daulah Umayyah dan Abbasiah. Sementara pertengahan adalah sastra Daulah Mamluk dan Ottoman. Sedangkan sastra modern adalah sastra yang muncul sejak munculnya gerakan kemerdekaan negara-negara Arab pada abad $13 \mathrm{H}$. hingga masa kini.

Pada pembagian di atas sejarawan tidak menyebutkan sastra Arab di Andalusia karena memasukkanya dalam bagian sastra Abbāsī. Sasrtra ini tumbuh di Andalusia atau Spanyol. Sastra ini bermula ketika Thoriq Bin Ziad dan Musa bin Nushair menaklukkan Andalusia pada masa Daulah Umayyah dan berakhir dengan jatuhnya Granada ke tangan pasukan Spanyol.

Nama Andalusia diambil dari Vandal, nama bangsa yang pernah menjajah Andalusia sebelum kemudian diusir oleh Ghotia Barat yang terletak di semenanjung Iberia, sebuah wilayah yang terletak di barat daya benua Eropa. Sebelah utara dibatasi dengan gunung Malladetta, sebelah barat dibatasi oleh laut Gelap atau laut Barat, sebelah timur dibatasi oleh laut Rum atau laut Timur dan dari selatan dibatasi dengan laut Zuqoq (selat Gilblaltar) (Al-Fakhuri, 1987:787).

Farrukh dalam Tārīkhul-AdabilAraby (1981:33) menyebut satra Andalus dengan sastra Maghrib, lawan dari sastra Masyriq yang saat itu berpusat di Baghdad. Sastra Maghrib ini terdiri atas sastra Arab di Libya, Tunisia, Maroko dan Semenanjung Iberia. Suku asli wilayah sastra Maghrib adalah suku Barbar yang berbicara dalam beberapa dialek. Mereka terdiri atas Badui (belum mengenal peradaban dan hidup berpindah-pindah) dan Hadhori (mengenal peradaban dan hidup menetap).

Secara umum periodisasi sastra Arab Andalusia dapat dibagi menjadi 4, yaitu Andalusia sebagai provinsi yang dipimpin gubernur-gubernur, Daulah Umayyah, Mulūkut-Thawāif dan Daulah Bani Achmar. Pembagian ini berdasarkan kondisi sosial politik yang terjadi di Andalusia.

\section{MASUKNYA KEBUDAYAAN ARAB KE ANDALUSIA}

Kebudayaan Arab masuk ke Andalusia pada zaman Al-Walid, Khalifah Daulah Bani Umayyah atas permintaan Andalusia yang hidup dalam ketidakstabilan politik. Pada waktu itu Andalusia berada di bawah jajahan bangsa Gothia. Yulian salah satu pangeran dan menantu raja Gothia yang memerintah pada waktu itu kemudian meminta bantuan Khalifah Bani Umayyah untuk melepaskan mereka dari kekuasaan Gothia setelah sebelumnya, pada zaman Utsman Bin Affan, Uqbah bin Nafi' membangun kota Qoiruwan dengan masjid yang kemudian menjadi pusat ilmu dan peradaban Islam di Afrika Utara pada tahun $666 \mathrm{M}$. Qoiruwan yang saat itu berada dalam wilayah provinsi Mesir menjadi cikal bakal bagi peradaban Arab-Islam di Maghrib.

Sejak kedatangan Islam di Andalusia, bukan hanya suku asli Barbar saja yang tinggal di Andalusia. Akan tetapi 
penduduk Maghrib bisa dibagi dalam dua kelompok besar, yaitu Muslim dan NonMuslim. Orang Muslim terdiri atas orang Arab yang datang dari Timur bersama Thoriq Bin Ziad, atau Baladiyyūn dan orang Arab yang datang bersama AlQusyairy pada zaman Andalusia sebagai provinsi yang dipimpin oleh para gubernur, atau Syāmiyyūn. Selain orang Arab, ada suku Barbar yang pindah ke Andalusia setelah penaklukan Islam dan Muwalladūn atau Mawālì, yaitu orang Nasrani Andalusia yang memeluk Islam. Adapun Non-Muslim terdiri atas Musta'ribūn yaitu Nasrani Andalusia yang berbahasa Arab; 'Ajam yaitu Nasrani Andalusia yang tidak berbahasa Arab; Romawi, Spanyol, Gothia, yaitu pendatang Nasrani atau Nasrani pada umumnya dan Yahudi (Farukh, 1981:39).

Pada periode awal ini tidak ditemukan naskah sastra Maghrib baik puisi maupun prosa. Jikalau ada itu adalah pidato Thoriq bin Ziad ketika menaklukkan Andalusia, atau puisi Musa bin Nushair. Namun para sejarawan berbeda pendapat mengenai naskah-naskah sastra tersebut. Pendapat terkuat mengatakan bahwa itu bukanlah sastra Maghrib, namun sastra Masyriq. Karena pada periode ini penduduk Andalusia belum mengenal bahasa Arab dengan baik. Sebagaimana di Syam (Syria, Lebanon, Yordania dan Palestina), Daulah Umayyah juga melakukan Arabisasi di Andalusia, yaitu menggunakan bahasa Arab dalam kehidupan sosial-politik mereka. Para khalifah mengirimkan guru-guru dari Masyriq untuk mengajarkan Al-Qur'an, Islam dan bahasa Arab kepada penduduk Maghrib. Sehingga Bahasa Arab menjadi bahasa utama Andalusia. Para guru ini mengajarkan bahasa Arab, Islam dan sastra di masjid-masjid. Mereka antara lain AlGhazi bin Qois.

DAULAH UMAYYAH DI DAMASKUS

Pada tahun 132 H As-Saffah mengumumkan berdirinya kerajaan Islam baru, yaitu Daulah Abbasiyah setelah sebelumnya membunuh khalifah, gubernur dan semua pendukung setia Daulah Umayyah. Lebih dari itu, As-Saffah membakar seluruh tulang-belulang khalifah Bani Umayyah kecuali Khalifah Umar Bin Abdul Aziz. Daulah Umayyah adalah ancaman besar bagi Daulah Abbasiyah. Namun As-Saffah menyisakan satu khalifah Daulah Umayyah yang berhasil melarikan diri dan membangun Daulah Umayyah baru di Andalusia, yaitu Abdurrahman bin Muawiyyah bin Hisyam bin Abdul Malik bin Marwan. Keberhasilannya ini membuatnya dijuluki dengan Ad-Dakhīl dan Shoqr Quraisy. AdDakhīl membangun Daulah Umayyah di Andalusia pada tahun $138 \mathrm{H}$. dengan ibukota Cordoba. Ad-Dakhīl tidak memakai gelar khalifah, namun amīr (pangeran) untuk menghormati khalifah Daulah Abbasiyah di Baghdad.

Jika pada periode awal belum ditemukan naskah sastra Arab Maghrib, maka masuknya ad-Dakhīl dan pengikut setianya memberikan pengaruh kuat bagi sastra Arab Andalusia. Pada periode ini mulai ditemukan naskah-naskah sastra Arab Maghrib. Naskah-naskah ini menggunakan kata, gaya bahasa dan tujuan yang sama dengan sastra Masyriq. Ini tidak mengejutkan karena sastrawan Maghrib menjadikan sastrawan Masyriq sebagai idola mereka. Karya-karya sastra Masyriq menjadi referensi utama. Baik dalam tema pujian, rayuan, celaan, arak, ratapan atau tema lainnya. Namun dalam menyusun naskah, sastrawan Maghrib menggunakan pilihan kata yang mudah dengan gambaran keindahan dan kekuatan emosi. Irama yang digunakan juga istimewa. Kekayaan alam, kondisi sosial masyarakat Andalusia turut mewarnai karya sastra Maghrib. Andalusia terletak di wilayah yang lebih istimewa jika dibandingkan dengan jazirah Arab. Cuaca yang bersahabat lengkap dengan taman hijau dan langit yang membiru. Lebih dari itu Andalusia dikelilingi oleh sungai dan laut yang tidak dapat ditemukan di Masyriq. Kondisi sosial yang majmuk antara penduduk Eropa, suku asli Maghrib 
Barbar dan penduduk Arab menjadikan emosi dan kultur yang sangat berbeda dengan kultur Masyriq yang keras dan kering.

Di samping mempertahankan corak sastra Masyriq, Muqoddam Bin Mu'afa alQobrī membuat terobosan baru dengan menulis muwasysyach, yaitu puisi yang tidak terikat pada keteraturan sajak dan tidak tunduk pada pola bunyi akhir. Namun sayangnya naskah ini tidak sampai ke tangan kita. Terobosan lain yang tidak ditemukan dalam sastra Masyriq adalah mu'ārodloh atau sastra tiruan seperti yang dilakukan oleh Yahya Bin Hakam alGhazal (Meninggal $250 \mathrm{H}$.) yang meniru kumpulan syair Khomr karya Abu Nuwas (Nafahut-Thib, 2:260-261). Ditambah lagi dengan masuknya Ziryab, Abul-Hasan Ali Bin Nafi' yang bersengketa dengan gurunya Ishaq Al-Maushilī ke Cordoba pada tahun $207 \mathrm{H}$ menjadikan sastra Arab pada masa Umayyah I ini lebih beragam.

Sastrawan yang dikenal pada zaman ini sebagian besar adalah khalifah dan pengikutnya. Belum banyak ditemukan naskah sastra Arab dari sastrawan suku asli atau non Arab karena minimnya pengetahuan bahasa yang mereka miliki pada masa ini. Di antara para sastrawan masa ini adalah Abdul Malik Bin Bisyr. Penyair rits $\bar{a}$ ' (ratapan), fakhr (bangga), hijā' (celaan) dan ghazal (rayuan). Seperti rayuan Abdul Malik Bin Bisyr dalam alHillah as-Sirō' (1:59) dalam Farukh (1981:65):

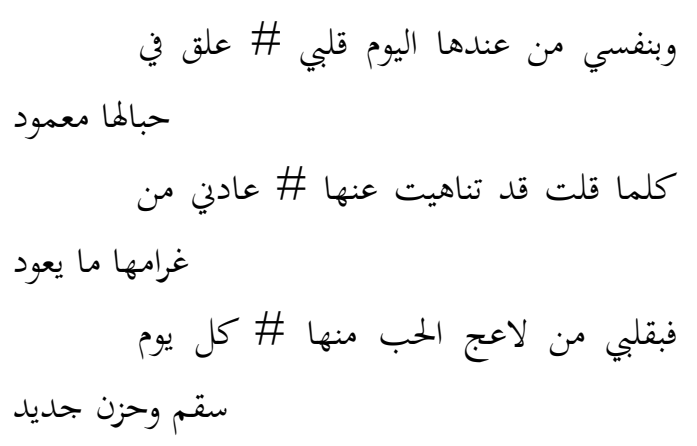

Wabinafsī: man indahal-yauma qolbī: \# 'Uliqo fi chibālihā ma'mūdu
Kullamā: qultu qod tanāhaitu 'anhā \# 'Ādan̄i: min gharāmihāa: mā ya' $\bar{u}: d u$

Fabiqolbī: min lā'ijil-chubbi minhā \# Kulla yaumin saqomun wachuznun jadìd

Artinya:

Demi jiwaku, sungguh dia telah menawan hatiku kini,

Hatiku dia buhul dalam ikatannya

Setiapkali aku berkata telah usai dari cintanya,

Hatiku kembali terpaut padanya

Demi hatiku yang terbakar cinta padanya,

Setiap hari yang dia rasakan hanya sakit dan sedih yang baru

Para pangeran Daulah Umawiyyah yang memimpin Andalusia selama 172 tahun berhasil membangun peradaban sosial politik Andalusia. Peradaban baru ini menjadi ancaman bagi Barat Eropa. Spanyol dan Vatikan berusaha untuk menggerogoti kekuatan peradaban Andalusia. Gerakan pelemahan kekuatan Arab di Andalusia ini dilakukan secara terus-menerus hingga masa Khalifah Abdurrahman An-Nashir. An-Nashir mengembalikan kejayaan Arab Andalusia kembali dan membangun kota Az-Zahra' pada tahun $325 \mathrm{H}$. dengan simbol masjid, istana dan kota yang indah dan megah.

Bagi pangeran dan khalifah Daulah Umawiyyah, Andalusia adalah kelanjutan Daulah Umawiyyah di Damaskus. Kehidupan sosial, mazhab fikih, ilmu, pemikiran dan sastra Maghrib adalah kelanjutan Daulah Umawiyyah di Masyriq. Sehingga para sejarawan sastra merasa kesulitan dalam membedakan antara sastra Masyriq dan Maghrib. Pada masa ini juga ditemukan syair-syair tiruan atau mu'āradlah. Seperti Ibnu Hani yang dikenal dengan Mutanabi Maghrib atau Ibnu Zaidun yang dikenal dengan Buhtury Maghrib. Di samping mu'āradlah beberapa tema mulai berkembang dengan emosi yang kuat dan imajinasi yang luas. Dalam tema washf (gambaran) muncul 
gambaran perang di laut, atau taman yang indah atau peradaban kota dengan bangunan-bangunan kokoh dan lingkungan masyarakat yang majemuk. Filsafat belum masuk ke Andalusia. Mazhab fikih yang ada masa ini hanya satu, yaitu mazhab Maliki. Seperti syair Ibnu Hani AlAndalusi ketika memuji Khalifah Al-Mu'iz lidinillah, (Farukh, 1981:196):

$$
\begin{aligned}
& \text { ما شئت، لا ما شاءت الأقدار! \# فاحكم، } \\
& \text { فأنت الواحد القهار! }
\end{aligned}
$$

Mà syi'ta, lā mā syā'atil-aqdār! \# Fachkum, fa'antal-wāchidul-qohhār Artinya:

Terserah padamu, bukan terserah pada taqdir

Hakimilah, karena engkaulah satu-satunya sang perkasa

Malāchim atau catatan kepahlawanan dan muwasysyach muncul pada masa ini. Sastrawan yang pertama kali menggunakan malāchim adalah Yahya Bin Hakam Al-Ghazal (meninggal 250 H.). Malāchim yang terkenal adalah malāchim Ibnu Abdi Rabbih (meninggal 328 H.) yang mencapai 450 bait yang menceritakan peperangan An-Nashir sejak $301-323 \mathrm{H}$. Adapun Muwasysyach seperti karya Ibnu Abdi Rabbih. Namun karya ini tidak sampai ke tangan kita.

Dalam bidang prosa, sastra Maghrib tidak mengalami perkembangan berarti sebagaimana syair. Hal ini disebabkan karena adanya riwāyah dan istisyhād atau penyebutan dalil dari al-Qur'an, Hadis, hikmah atau peribahasa. Dalam riwāyah seorang perawi ketika meriwayatkan teks akan berusaha keras untuk menggunakan kata-kata asli tanpa melakukan perubahan apapun. Begitu pula dalam istisyhād seorang sastrawan akan fokus pada pencarian dalil atas apa yang ia katakan. Sehingga kebiasaan mempertahankan sastra lama ini berimbas pada mempertahankan sastra lama dan tidak beranjak pada sastra baru. Seperti karya Al-'Iqdul-Farid karya Ibnu Abdi Robbih,
Al-Amālī karya Abu Ali Al-Qoli, Khutbah karya Al-Baluthi, Zahrul-Adab karya Chushri, Washiyyah karya Ibnu BurdilAkbar, Risālah Ibnu Syuhaid yang semuanya berusaha menggunakan gaya bahasa Masyriq.

Karya-karya di atas adalah karya non-fiksi. Adapun karya fiksi pertama adalah At-Tawābi' waz-Zawābigh karya Ibnu Syuhaid tahun $421 \mathrm{H}$. yang menceritakan tentang dunia jin. Karya ini ditemukan sebelum Risālatul-Ghufrōn karya Al-Ma'ari yang ditulis antara tahun 422 - 424 H. (Farrukh, 1981:202)

\section{MASA MULŪKUT-THAWĀIF}

Para khalifah setelah An-Nashir bukanlah khalifah yang kuat. Para khalifah ini sibuk dengan dunia ilmiah dan sastra sehingga menghadapi krisis ekonomi. Di sisi lain, Arab Andalusia harus menghadapi serangan tak berkesudahan dari Spanyol Nasrani dan berbagai pemberontakan yang melemahkan kekuasaan para khalifah. Sehingga pada akhirnya para khalifah harus melepaskan kedaulatan kerajaan Islam Andalusia pada tahun 422 H. Para pangeran yang melakukan pemberontakan ini kemudian membangun kerajaan-kerajaan kecil. Masing-masing kerajaan terdiri atas satu atau dua kota yang dipimpin oleh seorang raja. Masa raja-raja kecil ini berlangsung selama kurang lebih 60 tahun, yaitu sejak jatuhnya Daulah Umayyah di Andalusia tahun $422 \mathrm{H}$. hingga Yusuf bin Tasyfin menyatukan kekuasaan para raja kecil ini pada tahun $484 \mathrm{H}$.

Pada masa Mulūkut-Thawāif ini para bangsawan hidup sangat mewah, membangun istana megah dan hidup berfoya-foya. Rakyat Andalusia hidup dalam kesulitan karena pajak yang harus dibayarkan sangat tinggi. Pajak-pajak yang mencekik ini membuat rakyat Andalusia berpindah dari satu kota menuju kota lain dengan harapan dapat menemukan kehidupan yang lebih baik di kota lain. Akan tetapi kondisi sulit ini menyebar ke seluruh wilayah Andalusia. 
Kehidupan yang sulit ini berbanding terbalik dengan dunia keilmuan dan kesusastraan yang terus berkembang. Muncul mazhab-mazhab baru dalam beragama. Seperti mazhab Dhohiri Ibnu Hazm Al-Andalusi yang kemudian mendapatkan penentangan yang keras dari mazhab Maliki yang pernah menjadi satusatunya mazhab yang diyakini kebenarannya oleh penduduk Andalusia. Ibnu Hazm membuat karya monumental Thauqul-Chamamah dalam puisi dan prosa. Tema syair Andalusia seperti pujian, ratapan, celaan, rayuan, arak, tasawuf dan lain-lain adalah sastra Abbasiyah Masyriq, namun sastrawan Andalusia mampu menggunakan susunan kata yang lebih nyata dan imajinatif. Seperti syair karya Farazdaq dari sastra Masyriq di bait pertama dan bait Bisyar dari sastra Maghrib:

$$
\begin{aligned}
& \text { يكسو السيوف دماء الناكثين \# ويجعل الهام تيجان } \\
& \text { القنا الذبل } \\
& \text { وإذا دخلتِ تقنعي \# بالحمر، إن الحسن أحمر }
\end{aligned}
$$

Yaksūs-suyūfu dimā'an-nākitsīn \# Wayaj'alul-Hāmu tījānal-qanādz-dzabli

Waidzā dakholti taqna' $\bar{\imath}$

\# bil-chumri, innal-chasana achmaru

Artinya:

Para pedang itu berselubung darah penghianat

Dahaga menjadi mahkota tombak yang langsing

Jika engkau masuk, maka engkau akan merasa puas

Dengan warna merah, karena sesungguhnya kebaikan itu adalah merah.

\section{MASA DAULAH MURĀBITHĪN (484 - 539 H.) DAN DAULAH} MUWACHCHIDĪN (524 - 674 H.)

Andalusia yang terpecah-pecah dalam beberapa wilayah kekuasaan, membuat bangsa ini terus-menerus berada dalam masa peperangan. Masing-masing wilayah menyerang dan bertahan. Para raja-raja kecil di Andalusia ini seringkali meminta bantuan raja-raja Spanyol atau raja-raja Maghrib lain. Salah satunya adalah Yusuf bin Tasyfin, penguasa Daulah Murābithīn Maghrib di Marrakesy. Mulanya Yusuf hanya membantu raja-raja wilayah-wilayah kekuasaan tersebut, namun tidak adanya perubahan situasi membuatnya kemudian menguasai Andalusia dalam 10 tahun sejak ia membantu raja-raja itu. Yusuf memerintah selama 50 tahun sejak 350-400 $\mathrm{H}$. Kekuasaannya menyatukan Islam di Maghrib dan Andalusia. Namun tidak semua wilayah Maghrib berada di bawah kekuasaannya seperti Libya yang berada di bawah kekuasaan Daulah Fathimiyyah atau salah satu wilayah kecil Tunisia di bawah kekuasaan Daulah Bani Ziri. Murābithīn menyatukan Andalusia dan mengembalikan rasa aman. Sehingga rasa ini mampu mengembalikan warga Andalusia yang semula hijrah kembali dan hidup di Andalusia. Penduduk Andalusia memulai kehidupan mereka dengan membuka lahan bercocok tanam dan membuat barang-barang industri yang berimbas pada kokohnya ekonomi Andalusia.

Di bidang pemerintahan, Daulah Murābithīn menjadikan Alqur'an dan Hadis sebagai dasar negara. Mazhab fikih yang dikenal hanya mazhab Maliki. Ilmu filsafat yang muncul masa ini, belum mampu diserap kaum muslimin. Para ahli fikih masih mengharamkan ilmu kalam. Prosa dan puisi masih sama dengan sastra masa Mulūkut-Thawāif, yaitu berkiblat kepada sastra Masyriq. Hal ini antara lain karena secara umum Daulah Murābithīn belum mengenal bahasa Arab dengan baik. Fokus utama penguasa adalah membentuk kerajaan Islam. Corak kehidupan mereka adalah Barbar Badui yang hidup nomaden dan lebih mengedepankan kekuatan fisik, bukan pemikiran.

Di bidang prosa, sastrawan Andalusi banyak meniru sastrawan Masyriq seperti dalam saja' (kesamaan huruf akhir setiap 
bait), iqtibās (kutipan ayat-ayat Alquran dan Hadis), matsal-chikmah atau pemakaian Luzūm mā là yalzam (jinās dalam ilmu Balaghah, atau kesamaan kata akhir setiap bait). Dalam hal ide dan dan makna, belum ditemukan kedalaman makna sebagaimana sastra Masyriq. AlMa'arri dan Al-Jachidz masih menempati posisi sastrawan yang banyak dirujuk oleh sastrawan Maghrib. Seperti Ibnu Abdul Ghofur dan As-Saraqustī yang meniru AlMa'ari dalam luzūm mā là yalzam. Atau Risālah Yusuf Bin Tasyfin yang mengutip pidato Abu Bakar As-Shiddiq ketika dibai'at menjadi Khalifah.

Berbeda dengan Daulah Murābithīn, Daulah Muwachchidīn pada mulanya bukanlah sebuah kerajaan yang memiliki akar wilayah tertentu. Kerajaan ini dibentuk oleh pengikut Amghar Bin Tumirta dari Tinamal (keturunan Hasan bin Ali) yang menamakan diri sebagai Muwachchidun, dari kata tauchīd. Tahun $517 \mathrm{H}$. Ibnu Tumirta dan penggantinya Abdul Mu'min menyerang Daulah Murābithīn hingga sampai ke Andalusia. Di antara sultan yang terkenal dari Daulah Muwachchidīn adalah Abu Ya'qub Yusuf, cucu Abdul Mu'min yang bergelar alManshūr Al-Muwachchidīn dan hidup pada masa Shalahuddin Al-Ayubi.

Al-Muwachchidīn adalah orangorang salafi yang hanya menggunakan Alqur'an dan Hadis sebagai dasar pijakan hukum mereka. Orang-orang salafi yang tidak berkiblat pada mazhab apapun, bahkan mengharamkan taklid dan memperbolehkan ijtihad bersyarat. Yaitu berdasarkan pada ilmu, keadilan dan mengetahui sumber dasar hukum utama Islam. Barangkali sikap para pemimpin inilah yang kemudian melahirkan berbagai penulisan ilmu-ilmu baru dalam dunia Islam.

Adapun Masyarakat yang hidup zaman Muwachchidīn dibagi menjadi tiga golongan, yaitu As-Sābiqūnal-Awwalūn (pengikut Al-Mahdi bin Tumirta); Al-Atba ${ }^{\text {' }}$ (masyarakat yang hidup setelah zaman Ibnu Tumirta atau tidak bertemu dengannya); dan Al-'Āmmah (masyarakat pada umumnya). Keluarga Abdul Mu'min Bin Ali menyebut diri mereka sebagai Sayyid (tuan) (Farrukh, 1981:363).

Masa pemerintahan Ya'qub $\mathrm{Al}-$ Manshur dikenal dengan banyaknya bangunan-bangunan yang didirikan. Seperti masjid, benteng dan rumah sakit, baik untuk umum maupun untuk orang gila. Selain itu, Ya'qub Al-Manshur juga membangun jembatan, saluran air, sumur dan membangun kota pertahanan untuk Andalusia dari serangan kerajaan Spanyol, yaitu kota Rabat. Dalam bidang keilmuan, Ya'qub Al-Manshur memberikan semangat kaum ilmuwan dengan menggaji para ahli fikih dan para pencari ilmu.

$$
\text { Masa kekuasaaan Daulah }
$$

Muwachchidīn adalah masa emas penulisan. Banyak ilmu-ilmu baru atau lama dibukukan. Para penulis ini menulis bidang keilmuan Alqur'an, Hadis dan fikih. Seperti As-Syathibī yang terkenal dengan syair-syairnya, As-Syāthibiyyah atau Hirzul-Amān̄̄ wa Wajhut-Tahān̄̄ yang terdiri atas 1173 bait atau Ibnu Abdil Barr. Sementara dalam bidang filsafat dan tasawuf muncul Ibnu Thufail dan Ibnu Rusyd. Sultan Ya'qub Al-Manshur yang memerintah pada masa itu sangat mencintai filsafat. Namun protes para ahli fikih membuatnya melepaskan diri dari filsafat dan lebih dari itu mengeluarkan perintah untuk membakar semua buku filsafat yang tidak ada kaitannya dengan kedokteran, matemika dan astronomi.

Pada masa ini mulai marak penulisan sejarah. Baik penulisan secara umum, berdasarkan periodisasi, berdasarkan kota atau menggunakan katalog tokoh. Hanya sangat disayangkan banyaknya buku-buku tersebut yang hilang dan tidak sampai ke tangan kita. Sejarawan yang hidup masa ini adalah Abu Bakar AtTajibī dengan buku Majmū' min RijālilAndalus dan Basykuwal yang menulis AsShillah sebagai kelanjutan dari buku Tārīkh Ulamā' al-Andalusi karya Ibnu alFardhi (meninggal 403H). 
Dalam bidang sastra, syair menempati posisi khusus pada zaman sultan Ya'qub Al-Manshur. Contohnya adalah kumpulan syair Rauchusy-Syi'ri wa Dauhisy-Syajar karya Abu Abdullah AlFihri dan Muwasysyachāt karya Abu Bakar bin Zuhri juga Ayyuhas-saqi, IlaikalMusytaki. Muncul jenis sastra baru, yaitu rits $\bar{a}^{\prime}$ (ratapan) kota atau rits $\bar{a}$ ' kerajaan yang nantinya semakin menguat pada masa kejatuhan Andalusia. Syair jenis ini mulai muncul sejak jatuhnya kota Toledo ke tangan kerajaan Spanyol. Syair ratapan terhadap jatuhnya kota atau kerajaan yang terkenal adalah syair ar-Rundi likulli syai' in idzā mā tamma nuqshān.

Syair selain sebagai media untuk mengungkapkan keindahan, juga digunakan sebagai media penulisan ilmu. Filsafat pun menggunakan syair sebagai media. Pada masa ini muncul penyair ahli filasafat. Meski syair para ahli filsafat ini menjadi berat terutama karena ide yang diusung, namun kekuatan imajinasi dan pilihan katanya menunjukkan kejeniusan sastrawan Andalusia. Meski demikian tema-tema filsafat menjadikan syair kehilangan gairah dan keindahannya. Jenis sastra ini hanya dimiliki sastrawan Andalusia. Tokoh sastrawan-filosof ini seperti Yahya Al-Ghazal, Ibnu Bajah, Malik Bin Wahab dan Al-Jayan̄̄ yang bergelar Syā'irul-Chukamā' atau Chakìmus-Syu'arā'. Karya-karya tersebut seperti Syudzūrudz-Dzahab, atau alChadāiq karya Ibnu Faraj.

Dalam bidang prosa, Ibnu Thufail menulis Hayy Bin Yaqdzan, yaitu kisah filsafat yang mengungkapkan hal-hal ilmiah dan filsafat yang bersatu dengan tasawuf dalam bentuk sastra. Ibnu Rusyd, ahli filsafat zaman ini juga menulis novel dengan judul Hayy Bin Yaqdzan. Namun karya Ibnu Rusyd tidak terlalu dikenal sebagaimana Hayy Bin Yaqdzan karya Ibnu Thufail. Ibnu Rusyd lebih dikenal karena kepiawaiannya dalam menerjemahkan buku-buku Aristoteles seperti Dìwān fis-Syi'r.

\section{DAULAH BANI ACHMAR}

Abad $7 \mathrm{H}$. Andalusia masih berada di bawah kekuasaan Daulah Muwachchidīn. Ketika Daulah Muwachchidīn di Maghrib melemah, para wali Andalusia saling bertikai. Muhammad bin Yusuf bin Hud, gubernur Zaragoza melepaskan diri dari kekuasaan Daulah Muwachchidīn dan memperluas wilayahnya hingga selatan Andalusia, Syatibah, Cordoba, Sevilla, Giblaltar hingga Marfa' Sabtah di Maghrib. Kekuasaan Bin Hud membuat Bin Nasr (Bani Ahmar) ingin mengambil alih kekuasaan Bin Hud setelah mampu menguasai Granada tahun $629 \mathrm{H}$. Sebagaimana yang terjadi pada masa Mulūkut-Thawāif, masing-masing gubernur meminta bantuan kerajaan Spanyol hingga pada tahun $648 \mathrm{H}$. Ferdinand mampu mengambil alih Sevilla, bukan Bani Ahmar yang menguasainya.

Meski perselisihan antar dua kekuasaan Islam Maghrib-Andalusia terus berlangsung, namun Spanyol pada masa ini belum mampu merebut Andalusia dari tangan kaum muslimin. Pada saat ini kekuatan Spanyol saling bersengketa. Aragon-Castilla saling menjatuhkan. Namun tahun 873-874 Raja Aragon, Ferdinand V menikahi Isabel, saudara Henry IV Raja Castilla. Kemudian Isabel naik tahta menggantikan Henri IV yang tutup usia. Kerajaan Aragon dan Castilla pun akhirnya bersatu. Kekuatan itu berhasil mengambil Granada dari tangan kaum muslimin, sehingga kaum muslimin harus meninggalkan Granada atau tinggal dengan 67 syarat, antara lain memeluk agama Nasrani.

Pada masa ini, kekuasaan Islam Andalusia mulai mengecil hingga akhirnya habis. Namun keterpurukan politik tersebut tidak membuat peradaban Islam melemah. Justru keilmuan dan penyusunan buku semakin berkembang pesat. Penyusunan buku terus berjalan. Baik ilmu agama seperti ilmu-ilmu Alquran, Hadis, fikih, sejarah atau keilmuan umum seperti sains, filsafat dan mantiq. Seakan kaum muslimin 
yang kehilangan rasa aman dan berada dalam krisis ekonomi, sosial dan politik melarikan diri dalam ilmu pengetahuan dan dunia tasawuf. Pada zaman ini ilmu tasawuf berkembang pesat. Tokoh tasawuf yang terkenal pada zaman ini adalah Imam Abu Abdullah Muhammad bin Yusuf bin Umar bin Syu'aib As-Sanusi dan Burhanuddin Ibrahim bin Mahmud AsSyadzili.

Bukan hanya tasawuf, sejarahpun mengalami perkembangan pesat. Sejarawan terkenal masa ini adalah Abdurrahman bin Khaldun (meninggal 808. H) atau lebih dikenal dengan Ibnu Khaldun. Dari ilmu sejarah muncul ilmu sosial dan politik. Dalam bidang politik, bukan hanya politik negara namun juga politik pribadi atau pernikahan. Seperti Tuchfatul-'Arūs Wa Nuzhatun-Nufüs karya Abu Abdullah Muhammad bin Ahmad AtTijani atau Kitabu Rawdlil-'Áthir fi Nuzhatil-Khātir yang dicetak dengan judul Tanwīrul-Bithah fì Ma'rifati KaifiyyatinNikāch karya An-Nafzawi yang kemudian diterjemahkan dalam bahasa Inggris, Perancis dan Jerman.

Ilmu pengetahuan, tasawuf dan sastra menempati singgasana utama di hati kaum muslimin Andalusia. Menurut Ibnu Khaldun, sebuah kerajaan tidak akan hidup selamanya. Masing-masing kerajaan memiliki usia tertentu untuk kemudian jatuh dan digantikan oleh kerajaan lain. Namun kehancuran kerajaan tersebut tentu menimbulkan kesedihan di hati penduduknya. Sastra ratapan yang dikenalkan oleh Ar-rundi pada abad $6 \mathrm{H}$. semakin berkembang pesat. Terutama sejak jatuhnya wilayah demi wilayah Islam ke tangan kerajaan Spanyol. Di Masyriq sastra ratapan semacam ini sudah ada seperti kasidah Hamzawiyyah karya Ubaidullah bin Qois Ar-Ruqoyyat (meninggal tahun $75 \mathrm{H}$.) atau Al-Buhturī yang meratapi kehancuran kota Almadain, Ibukota Persia. Pada mulanya para penyair meratapi jatuhnya Toledo ke tangan Alfonso VI tahun $478 \mathrm{H}$. Sejak itu syairsyair rataoan kota dan kerajaan semakin berkembang di Andalusia seperti ratapan Ibnu Abdun, "Ad-Dahru Yafja'u Ba'dalAin bil-Atsar". Selain mengungkapkan kesedihan mereka akan jatuhnya wilayah Islam Andalusia, para raja-raja Maghrib dan Andalusia juga menuliskan kesedihan mereka dalam surat yang mereka kirimkan ke masing-masing raja tersebut. Ketakutan dan kesedihan akan jatuhnya wilayahwilayah Islam Andalusia ini sudah muncul sejak masa Mulūkut-Thawāif. Maka kedatangan raja Muwachchidīn ke Andalusia disambut gembira, dan dipuji para penyair muslim, seperti Al-Waqassyi dalam :

$$
\text { فأبصر حفل المشركين طريدا ليت هل يمد لي المدي }
$$

Alā laita Syi'rī hal yamuddu li:1madā \# Fa'abshiru chaflalmusyrikīna tharīda

Artinya:

Wahai, tidakkah puisiku yang membentang sepanjang usiaku

Maka lihatlah bagaimana pestapesta kaum musyrikin itu

\section{Adab Al-Maulid}

Al-Maulid adalah peringatan kelahiran Rasulullah SAW. Perayaan ini tidak dikenal pada masa Rasul dan para khalifah Rasul. Perayaan ini baru muncul pada masa Daulah Fathimiyyah abad $4 \mathrm{H}$ di Maghrib-Mesir. Daulah Fathimiyyah mengumpulkan kaum muslimin tiap 12 bulan Rabiulawwal dengan pembacaan sejarah Nabi Muhammad SAW. Pembacaan ini kemudian berkembang dan tidak hanya dilakukan pada tanggal ini saja, akan tetapi juga acara-acara sosial lainnya. Shalahuddin al-Ayyubī bahkan meminta kaum muslimin untuk berkumpul dan membaca sejarah Nabi pada hari-hari raya Nasrani di tempat dan waktu yang diacak untuk menjaga kaum muslimin.

Kebiasaan ini kemudian berkembang di Syam, Mesir dan Iraq selama beberapa waktu hingga sampai ke Maghrib dan Andalusia. As-Sakhawī 
menjelaskan dalam At-Tibril-Masbūk fì Nashīhatil-Mulūk, "Kaum Muslimin mengadakan perayaan pada bulan kelahiran Nabi Muhammad SAW. Mereka mengadakan walimah. Pada malam harinya menyedekahkan bermacam-macam makanan dan berlomba membaca dan menyenandungkan sejarah Nabi. Mereka nampak bahagia. Seorang sultan pada malam itu akan menempati tempat khusus. Aku menyaksikan peringatan ini pada malam tahun $785 \mathrm{H}$. di rumah Barquq."

Ka'ab bin Zuhair bin Abi Sulma (meninggal $26 \mathrm{H}$.) adalah sastrawan yang pertama kali membuat pujian kepada Rasulullah SAW. Di Masyriq penyair pujian kepada Rasul antara lain Ibnu alMaghribi Abul Qosim bin Husain bin Ali, Abul Faraj al-Jauzi dan Ibnu Hajar alHaitami. Adapun penduduk Maghrib yang menulis syair pujian kepada Rasulullah sangatlah banyak. Seperti Abul Abbas bin al-Arif as-Shufi:

$$
\begin{aligned}
& \text { وحقك، يا محمد، إن قلبي بحجك قربة نحو الإله } \\
& \text { جرت أمواه حبك في فؤادي فهام القلب في طيب } \\
& \text { المياه } \\
& \text { فصرت أرى الأمور بعين حق وكنت أرى الأمور } \\
& \text { بعين لاهي } \\
& \text { إذا شغف الفؤاد به ودادا فهل ينهاه عن ذكراه }
\end{aligned}
$$

Wachaqquka ya Muchammadu Inna Qolbī \# Bichubbika qurbatun nachwal-ilāhī

Jarat amwāhu chubbika fĩ fuādī \# Fahāmal-qalbu fi thībil-miyāhi

Fashirtu aral-umūra bi'aini haqqin\# Wakuntu arol-umūro bi'aini lāhī

Idzā Syaghofal-fu'ādu bihī wudāda\# Fahal yanhāhu 'an dzikrāhu Nāhī?

Artinya :

Bagimu, wahai Rasul. Sesungguhnya hatiku

Mencintaimu serupa cinta Tuhan
Bibir-bibir mengalirkan cintamu ke hatiku

Maka hati ini rindu akan kejernihan hati

Cinta ini membuatku melihat segalanya dengan tatapan 'ain haqq

Dan dahulu aku menatap segalanya dengan mata lahin

Jika hati telah terpaut akan cintanya

Mampukah para penguasa itu melarang untuk mengingatnya?

\section{PENUTUP}

Sastra Arab Andalusia adalah bagian sastra Arab yang semasa dengan sastra Abbasi. Sastra Arab ini sangat istimewa dengan akulturasi budaya Arab-AfrikaEropa. Akulturasi budaya ini menjadikan sastra Arab Andalusia unik dengan munculnya jenis sastra yang hanya ada di Maghrib dan tidak ditemukan di Masyriq. Kekuatan alam, kondisi sosial dan baru mengenal bahasa Arab juga di samping keinginan untuk meniru dan menjadikan sastra Masyriq sebagai kiblat ikut menambah karakteristik unik sastra Maghrib dan tidak kehilangan kekhasannya. Sastra Andalusia adalah bagian dari sastra Maghrib, namun sastra di Andalusia jauh lebih berkembang di banding sastra Maghrib pada umumnya.

\section{DAFTAR PUSTAKA}

Al-Fakhuri, Hana. Al-Jāmi' fī TārīkhilAdabil-Arabi. 1986. Beirut : DarulJail

Ar-Rafi'i, Mushthafa Shadiq. Tārīkh Adabil-Arab. 2000. Beirut: DarulKutubil-Ilmiyyah

Zaidan, Jurji. Tārikh Adabil-LughatilArabiyyah. Mesir: Darul-Hilal

Brockelman, Carl. Tārīkhul-Adabil-Arabi. Kairo: Darul-Ma'arif 
Farrukh, Umar. Tārīkhul-Adabil-Arabi. 1981. Beirut:Darul-Ilmi LilMalayin.

Jami'ah Al-Imam Muhammad Bin Muhammad Su'ud al-Islamiyyah (LIPIA). Shuwarun minash-Shīrah.. Riyadh: Al-Jami'ah.

Jami'ah Al-Imam Muhammad Bin Muhammad Su'ud al-Islamiyyah
(LIPIA). Al-Adabu lil-Mustawa AtsTsālits. Riyadh: Al-Jami’ah.

Jami'ah Al-Imam Muhammad Bin Muhammad Su'ud al-Islamiyyah (LIPIA). Al-Adabu. 1994. Riyadh: Al-Jami'ah. 